\title{
Epidural anesthesia and cancer outcomes in bladder cancer patients: is it the technique or the medication? A matched-cohort analysis from a tertiary referral center
}

\author{
Juan Chipollini ${ }^{1}$, Brandon Alford ${ }^{2}$, David C. Boulware ${ }^{3}$, Patrice Forget ${ }^{4}$, Scott M. Gilbert ${ }^{1}$, Jorge L. Lockhart ${ }^{1}$,
} Julio M. Pow-Sang ${ }^{1}$, Wade J. Sexton ${ }^{1}$, Philippe E. Spiess ${ }^{1}$, Michael A. Poch ${ }^{1}$ and Sephalie Y. Pate $\left.\right|^{5^{*}}$ (D)

\begin{abstract}
Background: The perioperative period can be a critical period with long-term implications on cancer-related outcomes. In this study, we evaluate the influence of regional anesthesia on cancer-specific outcomes in a radical cystectomy (RC) cohort of patients.

Methods: We performed a retrospective analysis of patients with clinically-nonmetastatic urothelial carcinoma of the bladder who underwent RC at our institution from 2008 to 2012. Patients were retrospectively registered and stratified based on two anesthetic techniques: perioperative epidural analgesia with general anesthesia (epidural) versus general anesthesia alone (GA). Epidural patients received a sufentanil-based regimen (median intraoperative sufentanil dose $50 \mathrm{mcg}(45,85)$. Propensity-score was used to make 1:1 case-control matching. Cumulative risk of recurrence with competing risks was calculated based on anesthetic technique. Kaplan-Meier curves were used to compare recurrence-free (RFS) and cancer-specific survival (CSS). Univariable and multivariable analyses were performed with Cox proportional hazard regression models for RFS and CSS.

Results: Only patients with complete data on anesthetic technique were included. Out of 439 patients, 215-pair samples with complete follow-up were included in the analysis. Median follow-up was 41.4 months (range: 0.20101). Patients with epidurals received higher median total intravenous morphine equivalents (ivMEQ) versus those in the GA group (75 (11-235) vs. 50 ivMEQ (7-277), $p<0.0001)$. Cumulative risk of recurrence at two years was $25.2 \%(19.6,31.2)$ for epidural patients vs. $20.0 \%(15.0,25.7)$ for GA patients (Gray test $p=0.0508)$. Epidural analgesic technique was a significant predictor of worse RFS (adjusted $H R=1.67,1.14-2.45 ; p=0.009)$ and CSS (HR $=1.53$, $1.04-2.25 ; p=0.030$ ) on multivariable analyses.
\end{abstract}

Conclusions: Epidural anesthesia using sufentanil was associated with worse recurrence and disease-free survival in bladder cancer patients treated with surgery. This may be due use of epidural sufentanil or due to the increased total morphine equivalents patient received as a consequence of this drug.

Keywords: Cystectomy, Epidural anesthesia, Perioperative period, Retrospective review

\footnotetext{
* Correspondence: Sephalie.Patel@Moffitt.org

${ }^{5}$ Department of Anesthesiology, Moffitt Cancer Center, 12902 Magnolia

Drive, Tampa, FL 33612, USA

Full list of author information is available at the end of the article
}

(c) The Author(s). 2018 Open Access This article is distributed under the terms of the Creative Commons Attribution 4.0 International License (http://creativecommons.org/licenses/by/4.0/), which permits unrestricted use, distribution, and reproduction in any medium, provided you give appropriate credit to the original author(s) and the source, provide a link to the Creative Commons license, and indicate if changes were made. The Creative Commons Public Domain Dedication waiver (http://creativecommons.org/publicdomain/zero/1.0/) applies to the data made available in this article, unless otherwise stated. 


\section{Background}

The perioperative period is a critical period which may impact long-term cancer outcomes. A complex state of inflammation, immunosuppression, angiogenesis, and high adrenergic state has been shown to potentially facilitate growth of residual disease and promote seeding of circulating tumor cells [1-3]. Thus, tumor surveillance and eradication are strongly dependent on an adequate immune response to these potentially influencing tumor biology [4-6].

Radical cystectomy (RC) with pelvic lymph node dissection is the mainstay treatment for muscle invasive bladder cancer. A greater survival advantage has been shown at 2 years or more following $\mathrm{RC}$ as opposed to bladder-sparing modalities [7]. However, the surgical stress response might initiate a cascade of cellular, hormonal, and neuronal perturbations that leave patients susceptible to the pro-metastatic effects of tumor manipulation [4-6]. In addition, the choice of anesthetic technique may influence cancer outcomes in two ways. First, the immosuppressive effects of opioids, has been proposed to possibly influence immunogenicity during surgery in several solid organ malignancies thereby influencing cancer recurrence [8, 9]. Secondly, regional anesthesia such as epidural anesthesia may blunt the pro metastatic effect of surgical stress $[10,11]$.

If one can attenuate these perioperative pro-metastatic processes, the immediate postoperative period could become a window of opportunity to improve long-term oncologic control for surgical oncology patients. Given the paucity of studies in the urological and anesthetic literature, we aim to evaluate cancer outcomes in a matched cohort of patients undergoing $\mathrm{RC}$ at our institution. Our hypothesis was that tumor recurrence may be associated with the use of epidural opioids.

\section{Methods}

\section{Analgesia management and study population}

The study was approved by institutional review board. We retrospectively reviewed the medical records of all patients who underwent RC from January 2008 and December 2012 for clinically non-metastatic urothelial carcinoma of the bladder with curative intent. Patients were stratified based on anesthetic technique which included a standardized protocol of general endotracheal anesthesia with epidural (epidural group) or general endotracheal anesthesia alone (GA group). Epidural catheters were placed at the discretion of the anesthesiologist and surgeon. Catheters were placed between T10-T12 levels and dosed primarily with sufentanil during the intra and postoperative period (median intraoperative dose $=$ 50mcg, range 45-85). Patients without epidural catheters utilized patient-controlled analgesia with either intravenous morphine or hydromorphone.

Propensity score matching based on age, American Society of Anesthesiologists (ASA) score, and pathologic N and $\mathrm{T}$ stage was performed for those patients with complete analgesic data and surveillance follow-up. In total, 215 matched subjects from each cohort was produced and included in the final analysis (Fig. 1). A data driven approach was not used in selecting characteristics to adjust for, rather the authors chose factors which might cause an imbalance in comparing the two cohorts in subsequent analysis. We agree that a data-driven approach could have been used, but there were no significant differences when comparing cohorts. Additionally, propensity matching was performed using anesthesia type as the outcome, not survival. Consequently, the matching does not preclude effects of measured and unmeasured baseline characteristics. For this reason we also adjusted the multivariable models for these effects.

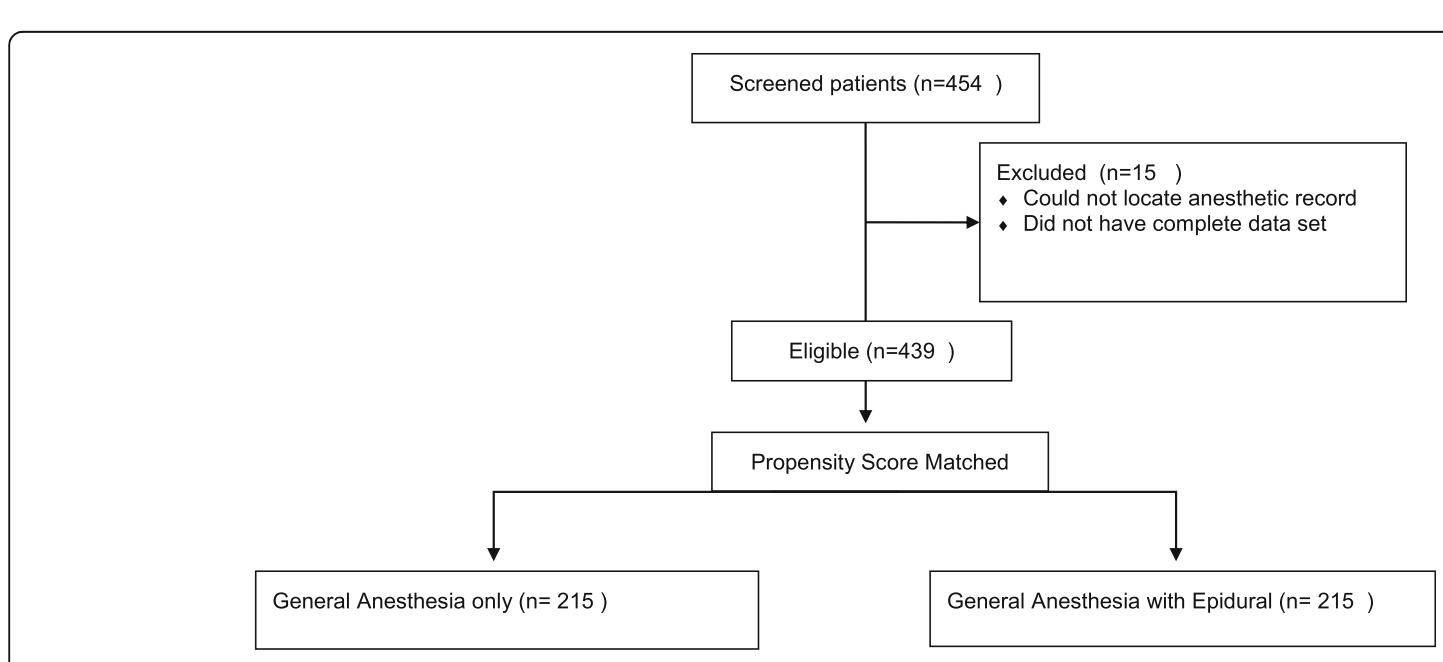

Fig. 1 Patient Flow Diagram 
Table 1 Characteristics of the sample ( $n=430$ patients)

\begin{tabular}{|c|c|c|c|}
\hline Variable & Level & $N=430$ & $\%$ \\
\hline \multirow[t]{2}{*}{ Gender } & Male & 332 & 77.2 \\
\hline & Female & 98 & 22.8 \\
\hline \multirow[t]{2}{*}{ Age (years) } & Median & 69 & - \\
\hline & Std Dev & 10.04 & - \\
\hline \multirow[t]{2}{*}{ BMI $\left(\mathrm{kg} / \mathrm{m}^{2}\right)$} & Median & 27.85 & - \\
\hline & Std Dev & 5.27 & - \\
\hline \multirow[t]{6}{*}{ Race } & White & 404 & 94.0 \\
\hline & Black & 14 & 3.3 \\
\hline & Asian & 1 & 0.2 \\
\hline & $\begin{array}{l}\text { Native Hawaiian/ } \\
\text { Pacific Islander }\end{array}$ & 1 & 0.2 \\
\hline & $\begin{array}{l}\text { American Indian/ } \\
\text { Alaskan }\end{array}$ & 1 & 0.2 \\
\hline & Unknown/Other & 9 & 2.1 \\
\hline \multirow[t]{4}{*}{ ASA score } & 1 & 3 & 0.7 \\
\hline & 2 & 194 & 45.1 \\
\hline & 3 & 224 & 52.1 \\
\hline & 4 & 9 & 2.1 \\
\hline \multirow[t]{2}{*}{ Anesthesia groups } & General only & 215 & 50.0 \\
\hline & General + Epidural & 215 & 50.0 \\
\hline \multirow{3}{*}{$\begin{array}{l}\text { Neoadjuvant } \\
\text { chemotherapy }\end{array}$} & No & 305 & 71.4 \\
\hline & Yes & 122 & 28.6 \\
\hline & Unknown & 3 & - \\
\hline \multirow[t]{4}{*}{ Diversion Type } & Ileal conduit & 280 & 65.1 \\
\hline & $\begin{array}{l}\text { Continent } \\
\text { catherizable pouch }\end{array}$ & 15 & 3.5 \\
\hline & Neobladder & 67 & 15.6 \\
\hline & $\begin{array}{l}\text { Cutaneous } \\
\text { ureterostomy }\end{array}$ & 63 & 14.6 \\
\hline \multirow[t]{6}{*}{ pT stage } & T0 & 59 & 13.7 \\
\hline & $\mathrm{T} 1$ & 44 & 10.2 \\
\hline & $\mathrm{T} 2$ & 82 & 19.1 \\
\hline & $\mathrm{T} 3$ & 125 & 29.1 \\
\hline & $\mathrm{T} 4$ & 62 & 14.4 \\
\hline & $\mathrm{Ta} / \mathrm{Tis}$ & 58 & 13.5 \\
\hline \multirow[t]{5}{*}{ pN stage } & $\mathrm{Nx}$ & 19 & 4.4 \\
\hline & N1 & 35 & 8.1 \\
\hline & N2 & 60 & 14.0 \\
\hline & N3 & 17 & 4.0 \\
\hline & NO & 299 & 69.5 \\
\hline \multirow[t]{2}{*}{ Radial margin } & Negative & 377 & 87.7 \\
\hline & Positive & 53 & 12.3 \\
\hline \multirow{2}{*}{$\begin{array}{l}\text { Ureteral or } \\
\text { urethral margin }\end{array}$} & Negative & 402 & 93.5 \\
\hline & Positive & 28 & 6.5 \\
\hline Grade & High & 350 & 96.7 \\
\hline
\end{tabular}

Table 1 Characteristics of the sample ( $n=430$ patients) (Continued)

\begin{tabular}{llll}
\hline Variable & Level & $N=430$ & $\%$ \\
\hline & Low & 5 & 1.4 \\
& Mixed & 2 & 0.6 \\
Adjuvant & Missing & 73 & - \\
chemotherapy & No & 340 & 79.8 \\
& Yes & 86 & 20.2 \\
Location of & Missing & 4 & - \\
Recurrence & Pelvic & 22 & 16.5 \\
& Upper tract & 11 & 8.3 \\
& Distant & 97 & 72.9 \\
& Other & 3 & 2.3 \\
& None & 297 & - \\
\hline
\end{tabular}

\section{Primary outcomes}

Primary outcomes measured were recurrence-free (RFS) and cancer-specific survival (CSS). Survival was assigned from date of surgery until date of recurrence (RFS) or death from disease (CSS). Follow-up data were available through our institution's tumor registry, which tracks patients' death certificates and follow-up at other medical facilities. Reasons for censoring were lost of follow up and death from any other known cause with documented absence of detectable disease after regular follow up.

To investigate whether or not total perioperative use of systemic opioids was different, we compared total intravenous morphine equivalents (ivMEQ) given in the intraoperative and immediate postoperative period. The ivMEQ were calculated on the basis of $1 \mathrm{mg}$ morphine $=1 \mathrm{mcg}$ sufentanil, $0.2 \mathrm{mg}$ hydromorphone, and $10 \mathrm{mcg}$ fentanyl $[12,13]$.

\section{Statistical analysis}

Frequencies, means, medians, and ranges were used in the descriptive tables to characterize the data both in total and by anesthesia type. For a subgroup of the variables, nonparametric tests (Wilcoxon rank sum test or Kruskal Wallis test for continuous and Fisher's Exact test for categorical variables, respectively) were performed comparing anesthesia cohorts. Cumulative risk of recurrence with competing risks analysis was calculated based on anesthetic technique and compared with the Gray test. Death was the competing event. The Kaplan-Meier method was used to estimate RFS and CSS. Cox Proportional Hazards regression was used in both univariable and multivariable models for each endpoint. For CSS, backwards selection process was performed. For RFS, competing risk analysis was carried out. All analyses were performed in either SAS ( $\mathrm{v}$ 9.4) and R software. This study is written in accordance to the Strengthening 
Table 2 Characteristics of the cohorts with tests $(n=430)$
Covariate Level GA (Non-Epidural) Epidural

\begin{tabular}{|c|c|c|c|c|}
\hline Covariate & Level & $\begin{array}{l}\text { GA (Non-Epidural) } \\
N=215\end{array}$ & $\begin{array}{l}\text { Epidural } \\
N=215\end{array}$ & $P$-value \\
\hline \multirow[t]{2}{*}{ Gender } & Male & $176(81.86)$ & $\begin{array}{l}156 \\
(72.56)\end{array}$ & 0.021 \\
\hline & Female & $39(18.14)$ & $\begin{array}{l}58 \\
(27.44)\end{array}$ & \\
\hline Age (years) & Median & 70 & 69 & 0.384 \\
\hline $\begin{array}{l}\text { Follow-up } \\
\text { (months) }\end{array}$ & Median & 40.7 & 42.9 & 0.260 \\
\hline \multirow[t]{6}{*}{ Race } & $\begin{array}{l}\text { Unknown/ } \\
\text { Other }\end{array}$ & $7(3.26)$ & $2(0.93)$ & 0.181 \\
\hline & White & 197 (91.63) & $\begin{array}{l}207 \\
(96.28)\end{array}$ & \\
\hline & Black & $8(3.72)$ & $6(2.79)$ & \\
\hline & Asian & $1(0.47)$ & $0(0)$ & \\
\hline & $\begin{array}{l}\text { Hawaiian/P. } \\
\text { Islander }\end{array}$ & $1(0.47)$ & $0(0)$ & \\
\hline & Indian/Alaskan & $1(0.47)$ & $0(0)$ & \\
\hline \multirow[t]{3}{*}{ Ethnicity } & Unknown/Other & 138 (64.19) & $\begin{array}{l}140 \\
(66.12)\end{array}$ & 0.977 \\
\hline & $\begin{array}{l}\text { Not Hispanic/ } \\
\text { Latino }\end{array}$ & $73(33.95)$ & $\begin{array}{l}71 \\
(33.02)\end{array}$ & \\
\hline & Hispanic/Latino & $4(1.86)$ & $4(1.86)$ & \\
\hline \multirow[t]{4}{*}{ ASA } & 1 & $1(0.47)$ & $2(0.93)$ & 0.147 \\
\hline & 2 & $86(40)$ & $\begin{array}{l}108 \\
(50.23)\end{array}$ & \\
\hline & 3 & $123(57.21)$ & $\begin{array}{l}101 \\
(46.98)\end{array}$ & \\
\hline & 4 & $5(2.33)$ & $4(1.86)$ & \\
\hline $\begin{array}{l}\text { Length of } \\
\text { stay (days) }\end{array}$ & Median & 8 & 7 & 0.352 \\
\hline BMI $\left(\mathrm{kg} / \mathrm{m}^{2}\right)$ & Median & 28.46 & 27.75 & 0.191 \\
\hline \multirow[t]{6}{*}{ pT stage } & T0 & $31(14.42)$ & $\begin{array}{l}28 \\
(13.02)\end{array}$ & 0.096 \\
\hline & $\mathrm{T} 1$ & $20(9.3)$ & $\begin{array}{l}24 \\
(11.16)\end{array}$ & \\
\hline & $\mathrm{T} 2$ & $30(13.95)$ & $\begin{array}{l}52 \\
(24.19)\end{array}$ & \\
\hline & T3 & $71(33.02)$ & $\begin{array}{l}54 \\
(25.12)\end{array}$ & \\
\hline & T4 & $31(14.42)$ & $\begin{array}{l}31 \\
(14.42)\end{array}$ & \\
\hline & $\mathrm{Ta} / \mathrm{Tis}$ & $32(14.88)$ & $\begin{array}{l}26 \\
(12.09)\end{array}$ & \\
\hline \multirow[t]{5}{*}{ pN stage } & $\mathrm{Nx}$ & $10(4.65)$ & $9(4.19)$ & 0.808 \\
\hline & $\mathrm{N} 1$ & $19(8.84)$ & $16(7.44)$ & \\
\hline & N2 & 33 (15.35) & $\begin{array}{l}27 \\
(12.56)\end{array}$ & \\
\hline & N3 & $7(3.26)$ & $10(4.65)$ & \\
\hline & NO & $146(67.91)$ & 153 & \\
\hline
\end{tabular}

\begin{tabular}{|c|c|c|c|c|c|c|c|c|c|}
\hline & & \multirow{2}{*}{\multicolumn{3}{|c|}{$N=215 \quad N=215$}} & \multirow{3}{*}{ Covariate } & \multirow{3}{*}{ Level } & \multirow{3}{*}{$\begin{array}{l}\text { GA (Non-Epidural) } \\
N=215\end{array}$} & \multirow{3}{*}{$\begin{array}{l}\text { Epidural } \\
N=215\end{array}$} & \multirow{3}{*}{$P$-value } \\
\hline & & & & & & & & & \\
\hline \multirow[t]{3}{*}{ Gender } & \multirow[t]{2}{*}{ Male } & \multirow[t]{2}{*}{$176(81.86)$} & \multirow{2}{*}{$\begin{array}{l}156 \\
(72.56)\end{array}$} & \multirow[t]{3}{*}{0.021} & & & & & \\
\hline & & & & & & & & \multicolumn{2}{|l|}{$(71.16)$} \\
\hline & Female & $39(18.14)$ & $\begin{array}{l}58 \\
(27.44)\end{array}$ & & $\begin{array}{l}\text { Neoadjuvant } \\
\text { chemotherapy }\end{array}$ & No & $155(72.77)$ & $\begin{array}{l}150 \\
(70.09)\end{array}$ & 0.540 \\
\hline Age (years) & Median & 70 & 69 & 0.384 & & \multirow[t]{2}{*}{ Yes } & $58(27.23)$ & \multirow{2}{*}{$\begin{array}{l}64 \\
(29.91)\end{array}$} & \\
\hline Follow-up & Median & 40.7 & 42.9 & 0.260 & & & & & \\
\hline
\end{tabular}

Reporting in Observational and Epidemiological studies (STROBE) guidelines (www.strobe-statement.org).

\section{Results}

Study cohort characteristics

Demographic and tumor characteristics of the entire cohort are provided in Table 1. Overall, $77.2 \%$ of patients were male. Median age was 69 years and median clinical follow-up was 41.4 months (range: 0.20-101). Approximately $29 \%$ and $20 \%$ received neoadjuvant and adjuvant systemic treatments, respectively. The most common urinary diversion was the ileal conduit (65.1\%). Approximately 44 and $26 \%$ had pT3/T4 and pN+ disease, respectively. The positive radial and ureteral or urethral margin rates were 12.3 and $6.5 \%$, respectively.

The non-epidural cohort had more male patients $(81.9$ vs $72.6 \%)(p=0.021)$, as well as more patients with $\mathrm{T} 3 / 4$ tumor stage $(47.4$ vs $39.5 \%)(p=0.096)$. No significant differences were found for hospital length of stay, race, ethnicity, body mass index (BMI), median follow-up, node stage or chemotherapy status between the two groups (Table 2).

Patients in the epidural group had higher median total morphine equivalents versus those in the GA group (75 (11-235) vs 50 ivMEQ (7-277), $p<0.0001$ ) (Fig. 2). None of the patients received intraoperative non-steroidal anti-inflammatory drugs (NSAID). Postoperatively, the NSAID use was not available.

\section{Recurrence rates}

Of the 430 patients, 133 (30.9\%) developed a recurrence with the most common type being distant metastatic disease (72.9\%). A cumulative risk for recurrence plot is presented in Fig. 3. The median time to recurrence was 11 and 11.8 months for epidural and GA, respectively. Majority of recurrences occurred within 2 years after RC with rates of $20.0 \%$ (95\%CI: $15.0-25.7)$ and $25.2 \%$ (19.631.2) for GA vs. epidural patients, respectively (Gray test $p=0.051)$.

\section{Survival analysis}

Figure 4 shows survival curves based on anesthesia type. Five-year RFS and CSS for the whole cohort were $67.2 \%$ $(62.0-71.8)$ and $68.7 \%$ (63.3-73.5), respectively. Epidural 


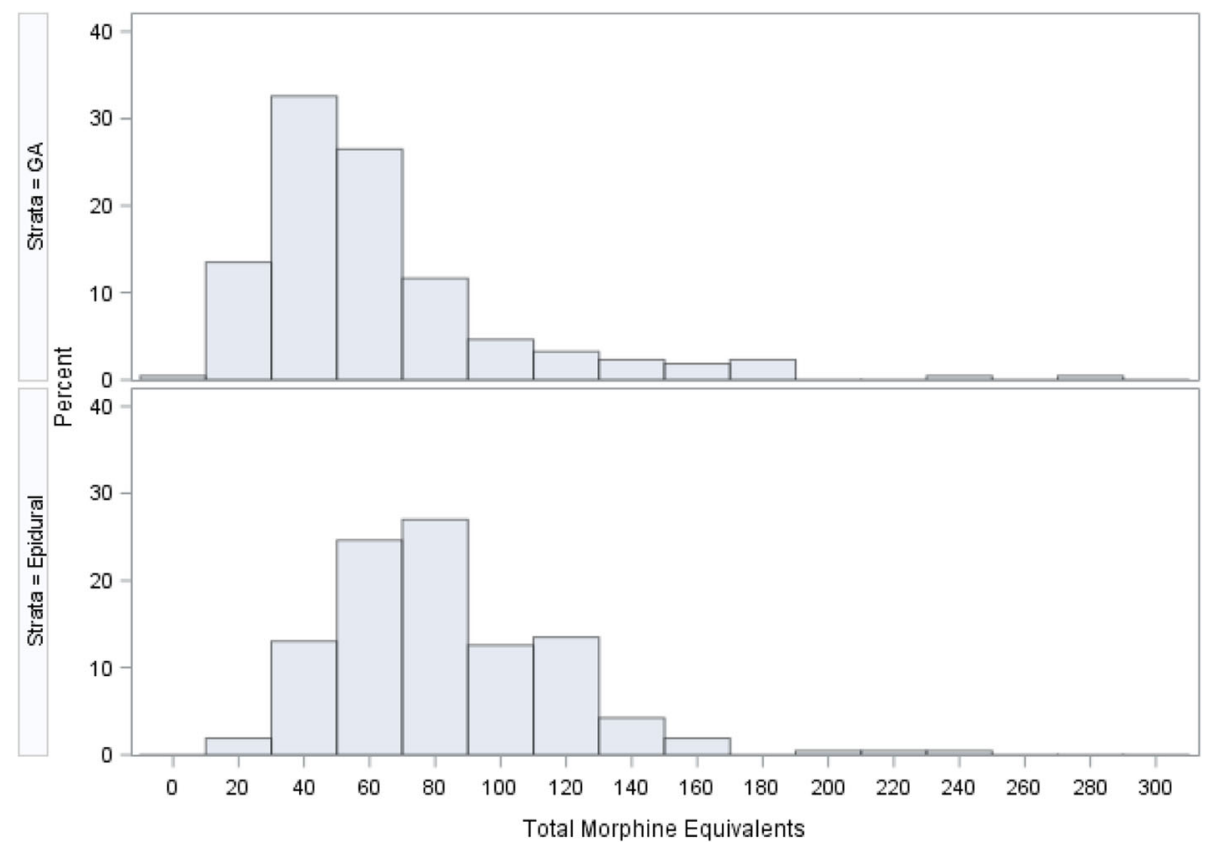

Fig. 2 Histogram of Total Morphine Equivalents by Anesthetic technique

patients had a 5-year RFS of $62.9 \%$ (55.4-69.4) vs. 70.9\% (63.5-77.2) for GA patients (log-rank $p=0.134$ ). Fiveyear CSS were $64.2 \%$ (95\% CI 56.2-71.1) and 73.7\% (95\% CI 66.0-79.8) (log-rank: $p=0.144$ ) for epidural vs. GA patients, respectively.

\section{Predictors for RFS and CSS}

Tables 3 and 4 show the results of Cox proportional hazards modeling for RFS and CSS, respectively. When adjusting for relevant covariates, patients who received epidurals were at increased risk of recurrence (adjusted $\mathrm{HR}=1.67,1.14-2.45 ; p=0.009$ ) and death of disease $(\mathrm{HR}=1.53,1.04-2.25 ; p=0.030)$. Other predictors of recurrence were age (adjusted $\mathrm{HR}=0.98, p=0.045$ ), $\mathrm{pT}$ stage (adjusted $\mathrm{HR}=2.22, p$ $<0.001$ ), and neoadjuvant chemotherapy (adjusted HR =1.66, $p=0.009)$ while $\mathrm{pN}$ stage $(\mathrm{HR}=2.48, p<$ $0.001)$, pT stage $(\mathrm{HR}=3.63, p<0.001)$, and margin status $(\mathrm{HR}=2.00, p=0.012)$ were associated with worse cancer survival.

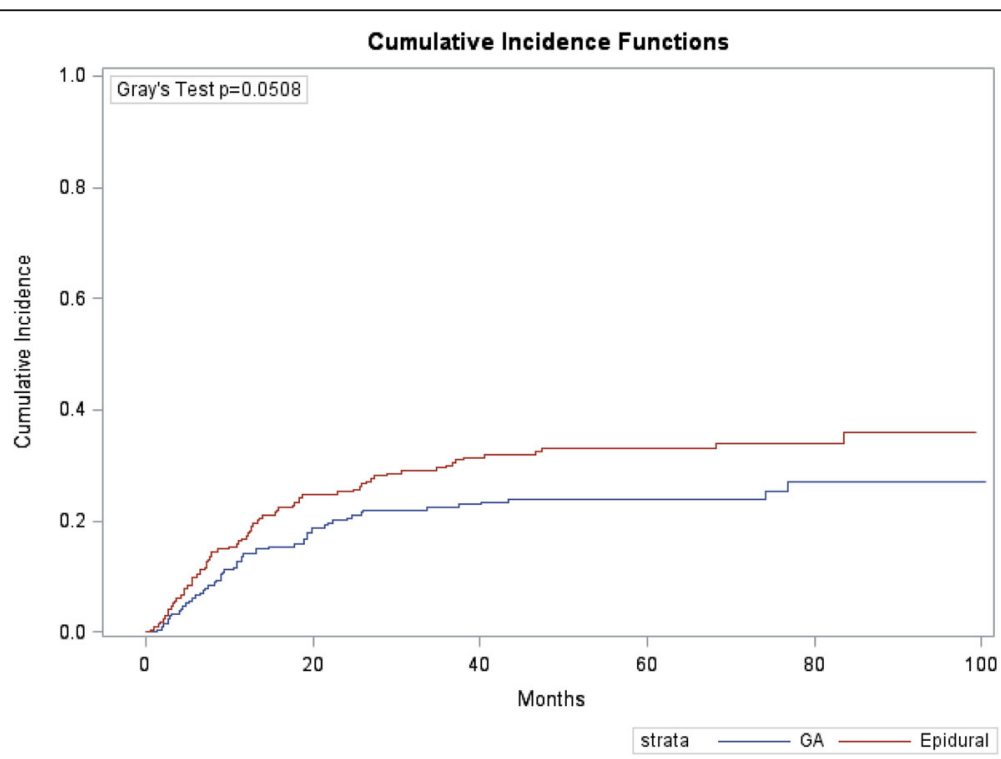

Fig. 3 Cumulative risk of recurrence between the two groups 


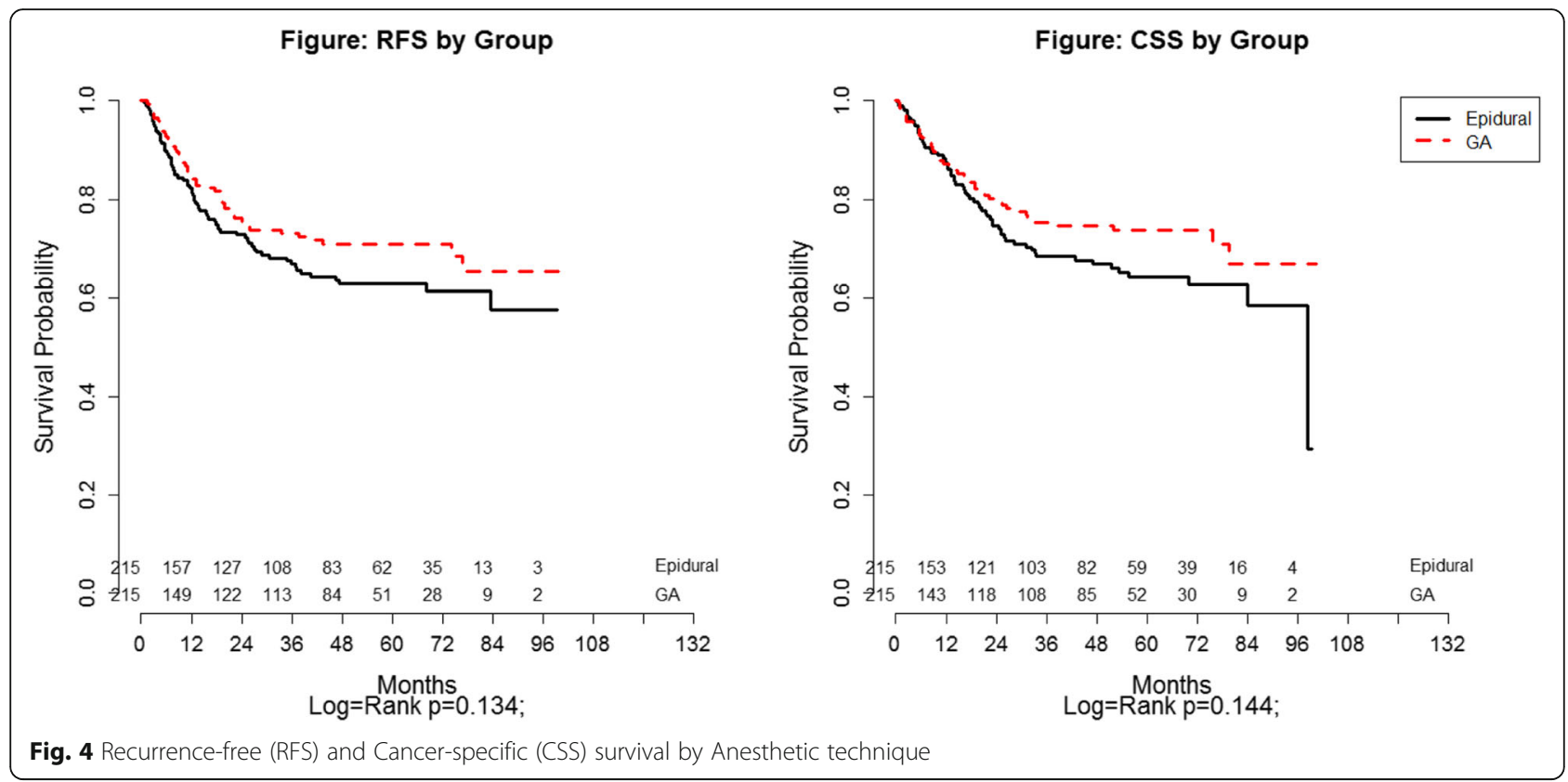

\section{Discussion}

Patients who received epidural analgesia sustained a decreased time to disease recurrence. Interestingly the log rank $p$-values (Fig. 4) did not show a statistical difference for RFS and CSS between groups, however the univariate Cox proportional hazard regression showed a statistical difference in RFS between the epidural and GA group. This is mostly likely due to the use of competing risk methods that was used in the RFS analysis. Since epidural sufentanil is such a potent opioid translating to a large ivMEQ, we believe the immunosuppressive effects of increased systemic opioids led to the poor recurrence and survival outcomes seen in our epidural cohort of patients [14].

The perioperative period is a fragile state for patients undergoing cancer surgery and is characterized by

Table 3 Cox proportional hazards regression for recurrence-free survival $(n=430)$ with competing risks

\begin{tabular}{|c|c|c|c|c|c|}
\hline Covariate & Level & $\begin{array}{l}\text { Univariable Hazard } \\
\text { Ratio }(95 \% \mathrm{Cl})\end{array}$ & $P$-value & $\begin{array}{l}\text { Multivariable Hazard } \\
\text { Ratio }(95 \% \mathrm{Cl})\end{array}$ & $P$-value \\
\hline Age & & $0.98(0.96-0.99)$ & 0.020 & $0.98(0.98-1.00)$ & 0.045 \\
\hline \multirow[t]{2}{*}{ Gender } & Male & $1.36(0.86-2.14)$ & 0.190 & $1.62(0.99-2.66)$ & 0.057 \\
\hline & Female & Ref & & & \\
\hline \multirow[t]{2}{*}{ ASA } & $\geq 3$ & $0.81(0.57-1.15)$ & 0.232 & $0.91(0.62-1.33)$ & 0.620 \\
\hline & $\leq 2$ & Ref & & & \\
\hline \multirow[t]{2}{*}{ Anesthesia } & GA + Epidural & $1.43(1.00-2.04)$ & 0.048 & $1.67(1.14-2.45)$ & 0.009 \\
\hline & GA & Ref & & & \\
\hline \multirow[t]{2}{*}{ pN stage } & $\mathrm{N}+$ & $1.76(1.21-2.55)$ & 0.003 & $1.24(0.82-1.88)$ & 0.308 \\
\hline & $\mathrm{NO} / \mathrm{Nx}$ & Ref & & & \\
\hline \multirow[t]{2}{*}{ pT stage } & $\geq T 3$ & $2.47(1.74-3.52)$ & $<0.001$ & $2.22(1.43-3.46)$ & 0.0004 \\
\hline & $\leq \mathrm{T} 2$ & Ref & & & \\
\hline \multirow{2}{*}{$\begin{array}{l}\text { Margin (radial/ } \\
\text { ureteral/urethral) }\end{array}$} & Positive & $1.42(0.95-2.12)$ & 0.091 & $1.23(0.78-1.94)$ & 0.370 \\
\hline & Negative & Ref & & & \\
\hline \multirow{2}{*}{$\begin{array}{l}\text { Neoadjuvant } \\
\text { chemotherapy }\end{array}$} & Yes & $1.69(1.18-2.43)$ & 0.005 & $1.66(1.14-2.43)$ & 0.009 \\
\hline & No & Ref & & & \\
\hline \multirow[t]{2}{*}{ Adjuvant chemotherapy } & Yes & $2.17(1.49-3.16)$ & $<0.001$ & $1.34(0.85-2.11)$ & 0.206 \\
\hline & No & Ref & & & \\
\hline
\end{tabular}

Bold value indicates statistical significance 
Table 4 Cox proportional hazards regression for cancer-specific survival $(n=430)$

\begin{tabular}{|c|c|c|c|c|c|}
\hline Covariate & Level & $\begin{array}{l}\text { Univariable Hazard } \\
\text { Ratio }(95 \% \mathrm{Cl})\end{array}$ & $P$-value & $\begin{array}{l}\text { aMultivariable Hazard } \\
\text { Ratio }(95 \% \mathrm{Cl})\end{array}$ & $P$-value \\
\hline Age & & $0.99(0.97-1.01)$ & 0.448 & & \\
\hline \multirow[t]{2}{*}{ Gender } & Male & $1.14(0.70-1.85)$ & 0.600 & & \\
\hline & Female & Ref & & & \\
\hline \multirow[t]{2}{*}{ ASA } & $\geq 3$ & $1.24(0.85-1.82)$ & 0.256 & & \\
\hline & $\leq 2$ & Ref & & & \\
\hline \multirow[t]{2}{*}{ Anesthesia } & GA + Epidural & $1.33(0.91-1.95)$ & 0.146 & $1.53(1.04-2.25)$ & 0.030 \\
\hline & GA & Ref & & & \\
\hline \multirow[t]{2}{*}{ pN stage } & $\mathrm{N}+$ & $3.70(2.52-5.43)$ & $<0.001$ & $2.48(1.64-3.74)$ & $<0.001$ \\
\hline & $\mathrm{NO} / \mathrm{Nx}$ & Ref & & & \\
\hline \multirow[t]{2}{*}{ pT stage } & $\geq \mathrm{T} 3$ & $4.98(3.31-7.51)$ & $<0.001$ & $3.63(2.32-5.68)$ & $<0.001$ \\
\hline & $\leq \mathrm{T} 2$ & Ref & & & \\
\hline \multirow{2}{*}{$\begin{array}{l}\text { Margin (radial/ } \\
\text { ureteral/urethral) }\end{array}$} & Positive & $2.38(1.56-3.62)$ & $<0.001$ & $2.00(1.29-3.09)$ & 0.012 \\
\hline & Negative & Ref & & & \\
\hline \multirow{2}{*}{$\begin{array}{l}\text { Neoadjuvant } \\
\text { chemotherapy }\end{array}$} & Yes & $1.34(0.90-1.99)$ & 0.151 & & \\
\hline & No & Ref & & & \\
\hline \multirow[t]{2}{*}{ Adjuvant chemotherapy } & Yes & $2.03(1.35-3.04)$ & 0.0006 & & \\
\hline & No & Ref & & & \\
\hline
\end{tabular}

${ }^{a}$ Results are from a backwards selection process (significance level at 0.05)

Bold value indicates statistical significance

various pro-metastatic processes such as release of tumor cells, increased levels of pro-angiogenic growth factors, and numerous hormonal and autonomic alterations caused by the surgery-induced stress response [15]. Thus, it is the synchronization of these detrimental processes that may render a patient susceptible to poor oncologic outcomes. Given that anesthesia and analgesia play an integral role in perioperative recovery and pain control, our study is significant in describing an association between anesthetic technique and cancer outcomes for bladder cancer patients.

Surgery induces a stress response that can affect the host's cytotoxic T-cell and natural killer (NK) cellular function, increase pro-angiogenic factors that promote tumor growth, and reduce circulating concentrations of tumor-related anti-angiogenic factors [16-19] In addition, systemic opioids used during hospital course can affect both humoral and cellular immunity by inhibiting antibody production, NK cell activity, cytokine expression, and phagocytic activity [14, 20-22].

One previous study of over 1000 prostatectomy patients reported intravenous sufentanil administration associated with increased risk of biochemical recurrence [8]. Interestingly, $97 \%$ of patients received sufentanil (epidural and intravenous) introducing a risk of type 1 error. Patients receiving intravenous sufentanil had a significant reduced survival rate (HR 7.8). The authors did not compare the dosage of sufentanil given through the epidural versus intravenously so we are unable to tell if the dosage was equal in both groups. If the intravenous sufentanil group received a higher ivMEQ, this would confirm previous observations that synthetic lipophilic opioids can negatively impact cancer-related outcomes. Given that our epidural cohort did not receive the opioid-sparing effect that is normally seen with hydrophilic opioid-based regional analgesia, our study adds support for decreased use of systemic opioids for patients recovering from cancer surgeries. Due to the inhibitory effects of opioids on not only NK cell function but also immunological pathways involving monocytes, secretion of immunoglobulins, cytokines and cell proliferation $[8,23]$, the increased systemic absorption caused by lipophilic, potent analgesics such as sufentanil may be detrimental for our cystectomy patients.

The issue of opioid use in the perioperative period has been increasingly recognized in the literature. The role of the $\mathrm{m} \mu$ opioid receptor (MOR), which has been shown expressed in cancer cells such lung adenocarcinoma and breast cancer, has been postulated as a mechanism of cancer progression due its interactions with angiogenesis, epithelial-mesenchymal transition, and the mammalian target of rapamycin signaling pathways [24-26]. These findings have been substantiated by retrospective data suggesting worse outcomes in patients with cancer who are exposed to systemic opioids and high levels of MOR expression [24, 27, 28]. Although our study adds more evidence on the detrimental effect of synthetic opioids, our findings require further translational studies which may 
help further characterize the pathophysiological basis of MOR inhibition and identify potential targets for future therapeutic strategies.

Several important limitations are inherent in this study including a limited sample size and the retrospective, observational design. Although we used propensity score matching to reduce selection bias, the effects of unmeasured confounding variables cannot be excluded. Our results relate to only sufentanil epidural anesthesia and do not translate to other neuraxial anesthetic techniques. Additionally, any association between anesthetic techniques and oncologic outcomes among patients with bladder cancer will need to be better characterized from a pathophysiological standpoint for our results to have not only epidemiological but therapeutic implications.

\section{Conclusions}

Worse oncologic outcomes may be associated with sufentanil based epidural anesthesia during radical cystectomy. This may have been due to the larger amount of opioids used with epidural sufentanil. Although limited by its retrospective design, our study suggests that further investigation in the clinical setting evaluating the effects of opioid-based epidural analgesia and bladder cancer progression is warranted.

\section{Abbreviations}

ASA: American Society of Anesthesiologists; BMI: Body Mass Index; CSS: Cancer Specific Survival; GA: General Anesthesia; HR: Hazard Ratio; ivMEQ: Intravenous morphine equivalents; MOR: Mu opioid receptor; NK: Natural Killer; NSAID: Non Steroidal Anti Inflammatory Drug; RC: Radical Cystectomy; RFS: Recurrence Free Survival; STROBE: Strengthening Reporting in Observational and Epidemiological Studies

\section{Acknowledgements}

None.

\section{Funding}

None.

\section{Availability of data and materials}

The datasets generated and analyzed during the current study are not publicly available due to HIPAA requirements.

\section{Authors' contributions}

All authors have read and approved the final manuscript. JC, SP, MP: Drafting of manuscript, analysis of data, study design. BA: Data collection. DB: Data analysis. PF, SG, JL, JP, WS, PS: Input in conception and design and drafting of manuscript.

Ethics approval and consent to participate

Study was approved by institutional review board and consent was waived due to retrospective nature of review.

\section{Consent for publication}

Consent was waived.

\section{Competing interests}

Patrice Forget is a Section Editor for BMC Anesthesiology.

\section{Publisher's Note}

Springer Nature remains neutral with regard to jurisdictional claims in published maps and institutional affiliations.

\section{Author details}

'Department of Genitourinary Oncology, Moffitt Cancer Center, 12902 Magnolia Drive, Tampa, FL 33612, USA. ' Morsani College of Medicine, University of South Florida, 12901 Bruce B. Downs Blvd, Tampa, FL 33612, USA. ${ }^{3}$ Department of Biostatistics and Bioinformatics, Moffitt Cancer Center, 12902 Magnolia Drive, Tampa, FL 33612, USA. ${ }^{4}$ Department of Anesthesiology, Vrije Universiteit Brussel (VUB), Universitair Ziekenhuis, Laarbeeklaan 101, 1090 Brussels, Belgium. ${ }^{5}$ Department of Anesthesiology, Moffitt Cancer Center, 12902 Magnolia Drive, Tampa, FL 33612, USA.

Received: 26 June 2018 Accepted: 19 October 2018

Published online: 03 November 2018

\section{References}

1. Eschwege P, Dumas F, Blanchet $P$, et al. Haematogenous dissemination of prostatic epithelial cells during radical prostatectomy. Lancet. 1995; 346(8989):1528-30.

2. Yamaguchi K, Takagi Y, Aoki S, Futamura M, Saji S. Significant detection of circulating cancer cells in the blood by reverse transcriptase-polymerase chain reaction during colorectal cancer resection. Ann Surg. 2000;232(1):58-65.

3. Wang JY, Wu CH, Lu CY, et al. Molecular detection of circulating tumor cells in the peripheral blood of patients with colorectal cancer using RT-PCR: significance of the prediction of postoperative metastasis. World J Surg. 2006:30(6):1007-13.

4. Ezhevskaya AA, Mlyavykh SG, Anderson DG. Effects of continuous epidural anesthesia and postoperative epidural analgesia on pain management and stress response in patients undergoing major spinal surgery. Spine (Phila Pa 1976). 2013:38(15):1324-30.

5. Lennard TW, Shenton BK, Borzotta A, et al. The influence of surgical operations on components of the human immune system. Br J Surg. 1985; 72(10):771-6.

6. Cakmakkaya OS, Kolodzie K, Apfel CC, Pace NL. Anaesthetic techniques for risk of malignant tumour recurrence. Cochrane Database Syst Rev. 2014;11: CD008877.

7. Ritch CR, Balise R, Soodana Prakash N, et al. Propensity matched comparative analysis of survival following chemoradiation or radical cystectomy for muscle invasive bladder cancer. BJU Int. 2018;121(5):745-51.

8. Forget $P$, Tombal $B$, Scholtes $\mathrm{J}$, et al. Do intraoperative analgesics influence oncological outcomes after radical prostatectomy for prostate cancer? Eur J Anaesthesiol. 2011;28(12):830-5.

9. Opioids RJ. cancer recurrence. Curr Opin Support Palliat Care. 2014;8(2):91-101.

10. Tedore T. Regional anaesthesia and analgesia: relationship to cancer recurrence survival. Br J Anaesth. 2015;115(2):34-45.

11. Perez-Gonzalex OCGL, Soliz J, Cata JP. Impact of regional anesthesia on recurrence, metastasis, and immune response in breast Cancer surgery: a systematic review of the literature. Reg Anesth Pain Med. 2017;42(6):751-6.

12. Anderson R, Saiers $\mathrm{JH}$, Abram S, Schlicht C. Accuracy in Equianalgesic dosing. J Pain Symptom Manag. 2001:21(5):397-406.

13. Waara-Wolleat KL, Hildebrand KR, Stewart GR. A Review of intrathecal fentanyl and Sufentanil for the treatment of chronic pain. Pain Med. 2006; 7(3):251-9.

14. Sprung J, Scavonetto F, Yeoh TY, et al. Outcomes after radical prostatectomy for cancer: a comparison between general anesthesia and epidural anesthesia with fentanyl analgesia: a matched cohort study. Anesth Analg. 2014;119(4):859-66.

15. Horowitz M, Neeman E, Sharon E, Ben-Eliyahu S. Exploiting the critical perioperative period to improve long-term cancer outcomes. Nat Rev Clin Oncol. 2015;12(4):213-26.

16. Shakhar G, Ben-Eliyahu S. Potential prophylactic measures against postoperative immunosuppression: could they reduce recurrence rates in oncological patients? Ann Surg Oncol. 2003;10(8):972-92.

17. Ikeda M, Furukawa $H$, Imamura $H$, et al. Surgery for gastric cancer increases plasma levels of vascular endothelial growth factor and von Willebrand factor. Gastric Cancer. 2002;5(3):137-41.

18. Maniwa Y, Okada M, Ishii N, Kiyooka K. Vascular endothelial growth factor increased by pulmonary surgery accelerates the growth of micrometastases in metastatic lung cancer. Chest. 1998:114(6):1668-75.

19. Holmgren L, O'Reilly MS, Folkman J. Dormancy of micrometastases: balanced proliferation and apoptosis in the presence of angiogenesis suppression. Nat Med. 1995;1(2):149-53. 
20. Mitsuhata H, Shimizu R, Yokoyama MM. Suppressive effects of volatile anesthetics on cytokine release in human peripheral blood mononuclear cells. Int J Immunopharmacol. 1995;17(6):529-34.

21. Moudgil GC, Singal DP. Halothane and isoflurane enhance melanoma tumour metastasis in mice. Can J Anaesth. 1997;44(1):90-4.

22. Melamed R, Bar-Yosef S, Shakhar G, Shakhar K, Ben-Eliyahu S. Suppression of natural killer cell activity and promotion of tumor metastasis by ketamine, thiopental, and halothane, but not by propofol: mediating mechanisms and prophylactic measures. Anesth Analg. 2003;97(5):1331-9.

23. Stefano GB, Kream R. Endogenous opiates, opioids, and immune function: evolutionary brokerage of defensive behaviors. Semin Cancer Biol. 2008; 18(3):190-8

24. Singleton PA, Moss J, Karp DD, Atkins JT, Janku F. The mu opioid receptor: a new target for cancer therapy? Cancer. 2015;121(16):2681-8.

25. Cata JP. Can the perioperative anesthesia Care of Patients with Cancer Affect Their Long-term Oncological Outcomes? Anesth Analg. 2017;124(5):1383-4.

26. Lennon FE, Mirzapoiazova T, Mambetsariev B, et al. The mu opioid receptor promotes opioid and growth factor-induced proliferation, migration and epithelial mesenchymal transition (EMT) in human lung cancer. PLoS One. 2014;9(3):e91577.

27. Nguyen J, Luk K, Vang D, et al. Morphine stimulates cancer progression and mast cell activation and impairs survival in transgenic mice with breast cancer. Br J Anaesth. 2014;113(Suppl 1):i4-13.

28. Ondrovics M, Hoelbl-Kovacic A, Fux DA. Opioids: Modulators of angiogenesis in wound healing and cancer. Oncotarget. 2017;8(15):25783-96.

Ready to submit your research? Choose BMC and benefit from:

- fast, convenient online submission

- thorough peer review by experienced researchers in your field

- rapid publication on acceptance

- support for research data, including large and complex data types

- gold Open Access which fosters wider collaboration and increased citations

- maximum visibility for your research: over $100 \mathrm{M}$ website views per year

At $\mathrm{BMC}$, research is always in progress.

Learn more biomedcentral.com/submissions 